\title{
INDICES OF RENEWAL OF EWE SEXUALACTIVITY AND ITS CORRELATION WITH AGE, WEIGHT, TRADITIONAL REPRODUCTIVE TRAITS AND CLIMATIC CONDITIONS
}

\author{
I. V. Lobachova, O. V. Ivanyna \\ LIV-post@ukr.net
}

Institute of Animal Husbandry in Steppe Regions «Ascania-Nova» named after M. F. Ivanov's National Scientific Selection-Genetic Centre of Sheep Breeding,

1 Soborna str., Ascania-Nova, Chaplynskyy district, Kherson region, 75230, Ukraine

To evaluate the quality of renewal of the sexual activity in ewes during the insemination campaign next indices were developed: $I H_{i}$ - the index of heat ( 0 or 1), IHT — the index of heat time (from 1 to 4), ICT - the index of conception time (from 1 to 4 ) and $I L_{i}$ - the index of lambing (from 0 to 3). Relationships between the indices and age, weight, part of animals with the heat (E\%), fertility (F\%), fecundity (Fm\%), prolificacy (Pf) and climatic condition were researched. Data of Ascanian Merino ewes of 6 years was used.

Dependences between the indices and age, weight, change of weight and reproduction traits were nonlinear. The IH index was increasing with the rise of age, but after 6 years began to decrease. The mean IHT, index was the highest in the youngest and oldest animals indicating that the first heat delays in ewe lambs and $\geq 8$-years old animals. Change of the ICT index showed that the youngest and oldest animals had the lowest success to become pregnant during the first heat. Level of correlation between the weight and its change from the one side and the indices from the other was high $(R>0.7)$ in young $(\geq 2$ years old) and moderate-noticeable $(0.3<R<0.7)$ in more aged animals. The IHT index had noticeable relationship with $E \%$, F\%, Fm\% and low $(R<0.3)$ with $\mathrm{Pf}$, the ICT index - high with $\mathrm{F} \%$ and $\mathrm{Fm} \%$ and low with Pf. The IHT index reliably negatively correlated with the average air temperature in May and June, the $I C T_{i}$ and $I L_{i}-$ with mean temperature in July. The average humidity in June reliably positively correlated with E\%, in July - with Pf.

It was supposed that the created indices may be useful to evaluate the efficiency of the applying of technological and selection approaches allowed to reducing of seasonality of sheep reproduction.

Keywords: EWE, REPRODUCTION, SEXUAL ACTIVITY, INDEX

\section{ІНДЕКСИ ПОНОВЛЕННЯ СТАТЕВОЇ АКТИВНОСТІ ОВЕЦЬ ТА ЇХ КОРЕЛЯЦІЯ З ВІКОМ, ВАГОЮ, ТРАДИЦІЙНИМИ ПОКАЗНИКАМИ ВІДТВОРЕННЯ ТА КЛІМАТИЧНИМИ УМОВАМИ}

\author{
I. В. Лобачова, О. В. Іванина \\ LIV-post@ukr.net
}

Інститут тваринництва степових районів імені М. Ф. Іванова «Асканія-Нова» - ННСГЦВ, вул. Соборна, 1, смт Асканія-Нова, Чаплинський р-н, Херсонська обл., 75230, Україна

Для оцінки якості поновлення статевої активності овець під час кампанії з осіменіння були розроблені такі індекси: $I_{i}$ - індекс охоти (0 або 1), IHT - індекс часу охоти (від 1 до 4), ICT - індекс часу запліднення (від 1 до 4) та $I L_{i}$ - індекс ягніння (від 0 до 3). Досліджено зв 'язок індексів з віком та вагою маток, часткою тварин з проявом охоти, (E\%), запліднюваністю (F\%), плодючістю (Fm\%), багатоплідністю (Pf) та кліматичними умовами. Використані дані вівцематок Асканійської Тонкорунної породи 6 послідовних років.

Залежності між індексами та віком, вагою, зміною ваги та показниками відтворення були нелінійні. Індекс IH зростав при збільшенні віку до 6 років, після чого починав зменшуватись. Значення індексу ІНТ було найвищим у наймолодиих та найстаріших тварин, щзо свідчило про затримку прояву першої статевої охоти у ярок та $\geq 8$-річних тварин. Варіаџія індексу ICT показала, щзо наймолодші та найстарімі тварини мають найгіриу ймовірність завагітніти під час першої статевої охоти. Рівень кореляиї між вагою і ї̈ зміною з одного боку та індексами з іншого був високим $(R>0,7)$ у молодих $(\geq 2$ років) та помірно-помітним $(0,3<R<0,7)-$ у стариих тварин. Індекс IHT, мав помітний зв 'язок з $E \%, F \%$ та Fm\% і слабкий $(R<0,3)-3$ Pf, індекс ICT високий з F\% та Fm\% і слабкий з Pf. Індекс IHT, негативно вірогідно корелював з середньою температурою повітря у травні та червні, індекси $I C T_{i}$ та $I L_{i}-$ з середньою температурою липня. Середня вологість повітря в червні позитивно вірогідно корелювала з E\%, у липні-з Pf. 
Припущено, щзо розроблені індекси можуть бути користними для оиінювання ефективності застосування технологічних та селекиійних прийомів, спрямованих на зменшення сезонності відтворення овеиь.

Ключові слова: ВІВЦЯ, ВІДТВОРЕННЯ, СТАТЕВА АКТИВНІСТЬ, ІНДЕКС

\title{
ИНДЕКСЫ ВОЗОБНОВЛЕНИЯ ПОЛОВОЙ АКТИВНОСТИ ОВЕЦ И ИХ КОРРЕЛЯЦИЯ С ВОЗРАСТОМ, МАССОЙ, ТРАДИЦИОННЫМИ ПОКАЗАТЕЛЯМИ ВОСПРОИЗВОДСТВА И КЛИМАТИЧЕСКИМИ УСЛОВИЯМИ
}

\author{
И. В. Лобачева, А. В. Иванина \\ LIV-post@ukr.net
}

Институт животноводства степных районов имени М. Ф. Иванова «Аскания-Нова» - ННСГЦО, ул. Соборная, 1, пгт Аскания-Нова, Чаплинский р-н, Херсонская обл., 75230, Украина

Для оченки качества возобновления половой активности овец во время кампании осеменения были разработаны следующие индексы: IH - индекс охоты (0 или 1), IHT - индекс времени охоты (от 1 до 4), $I C T_{i}$ - индекс времени оплодотворения (от 1 до 4) и $I L_{i}-$ индекс ягнения (от 0 до 3). Исследована связь индексов с возрастом, массой, долею животных с проявлением охоты (Е\%), фертильностью (F\%), плодовитостью (Fm\%), многоплодием (Pf) и климатическими параметрами. Использованы даннье овеи Асканийськой Тонкорунной породы 6 последовательных годов.

Зависимости между индексами и возрастом, массой, изменением массы и показателями воспроизводства были нелинейныли. Индекс $\mathrm{IH}_{i}$ возрастал с увеличением возраста до 6 лет, после чего начинал снижаться. Значение индекса IНТ было наибольшим у самых молодых и $\geq 8$-летних животных, что свидетельствует о задержке проявления первой половой охоты у ярок и старых животных. Вариаиия индекса ICT показала, что самые молодые и самые старые животные имеют наименьшую вероятность забеременеть во время первой половой охоты. Уровень корреляиии между массою и ее изменением с одной стороны и индексами с другой был высоким $(R>0,7)$ у молодых $(\geq 2$ годов) и умеренно-заметным $(0,3<R<0,7)$ у старшых животных. Индекс IHT имел заметную связь с E\%, F\% и Fm\% и слабую $(R<0,3)-c$ Pf, индекс ICT $T_{i}$ - высокую с F\% и Fm\% и слабую с Pf. Индекс IHT, отрицательно достоверно коррелировал со средней температурой воздуха в мае и июне, индексы $I C T_{i}$ и $I L_{i}$ - со средней температурой июля. Средняя влажность воздуха в июне положительно достоверно коррелировала с E\%, в июле - $c$ Pf.

Предположено, что разработанные индексы могут быть полезными для оченивания эффективности применения технологических и селекиионных приемов, направленных на уменьшение сезонности воспроизводства овеи.

\section{Ключевые слова: ОВЦА, ВОСПРОИЗВОДСТВО, ПОЛОВАЯ АКТИВНОСТЬ, ИНДЕКС}

High reproductive rates are a key of the successful livestock breeding. Sexual function is affected by many factors, one of which is seasonality. Seasonality of the animal reproduction is characterized by absence of sexual heat in certain months and manifestation in the other ones. For majority of sheep breeds the natural renewal of sexual activity is synchronized with the late summerearly autumn months. With right choice of start of the mating campaign the most ewes show heat at the first 2-3 weeks. However, in significant portion of animals the renewal of sexual activity delayed that leads to elongation of the lambing period and birth of weak lambs. To artificially accelerate and consolidate the insemination campaign, improve the renewal of sexual activity and reduce the influ- ence of seasonality the technological [3] and selection $[12,13]$ methods are used. However, in order to determine the effectiveness of both the ways, it is necessary to use the certain criteria of evaluation of its influence on reproduction.

There are two main types of indicators of evaluation of reproduction in ewes. The firsts include those, which based on description of lambs obtained from ewes, - the number of lambs born per ewe (litter size at birth, or prolificacy), the number of lambs weaned per ewe (litter size at weaning), total weight of lambs weaned (total lamb weight at weaning) and similar indices [5]. However, these indicators are more suitable for evaluation of the economic benefit of sheep breeding [10]. Indicators of the $2^{\text {nd }}$ group directly describe the re- 
production of ewes, but are used for animal groups and not for single individuals - portion of animals with oestrus, fertility, fecundity [17]. In total, these two types of indicators are based on final results of the "insemination-lambing" cycle and do not give much for evaluation of rate of the renewal of sexual activity, because does not take into account the time of the heat appearance.

Some researchers as the indicator of the rate of the oestrus appearance use the time between joining of rams and following ewe lambing [9]. But, in this case, they don't take in attention a chance of existence of the first heat, which doesn't completed by fertilization.

Because till now the indicators, which would allow to evaluate the quality of the renewal of sexual activity of ewes, has not been developed, the following tasks have been set: 1) to create the individual indices for evaluation of the renewal of sexual activity, which are linked to time of heat appearance, fertilization and lambing; 2) to investigate correlation between these indices, physiological parameters (age, weight and weight change before insemination) and traditional group's reproductive traits (portion of animals with heat, fertility, fecundity, prolificacy); 3) to analyse the correlation between the indices and the physical parameters of environment - air temperature, humidity, rainfall amount. The general task of research was to assess the suitability of the proposed indices for estimation the quality of the seasonal renewal of sexual activity in ewes.

\section{Materials and methods}

The research was carried out by processing of data journals of artificial insemination and lambing of ewes. Animals were kept in research farm of the Institute of Animal Husbandry "Ascania-Nova". Farm is located at $46^{\circ} 27^{\prime} \mathrm{N} 33^{\circ} 52^{\prime} \mathrm{E}$. In farm the autumn insemination with following winterspring lambing is practiced.

Climatic condition data was taken at meteorological station that located at a distance of 1 kilometre from place of animal keeping.

Animals. Experimental animals were ewes of the Ascanian Merino breed. This breed characterizes by seasonality of reproduction with beginning of natural appearance of heat in the third decade of August-first half of September and disappearance of ovulation in February-March [8]. Data of the insemination and lambing for 2011-2017 years have been used. During this period flock included animals, which at the time of insemination were 1-11-full years old. It did not take into account the data of those animals, which in some years were used in experiments for artificial stimulation or correction of sexual function, and those, which were not inseminated because of culling. In total, data of 1778 animals were processed, including 263 ewes for 2011-2012, 330 for 2012-2013, 350 for 20132014, 278 for 2014-2015, 311 for 2015-2016 and 246 for 2016-2017 years.

Animal keeping. Basic diet of all the ewes consisted of alfalfa-grass hay and corn silage. During the whole year $400 \mathrm{~g}$ of whole barley or cereal-corn mixture was daily fed to the ewes in the morning. Access to water was free. In the spring, summer and autumn months in the morning and in the evening animals grazed on the adjoining territory. 1-1.5 months before the start of the insemination campaign the mass of the grain mixture was increased to $600 \mathrm{~g}$ per animal. During the insemination campaign the morning grazing of ewes was being begun after end of procedure of heat detection. Animals, which showed heat and were inseminated, did not were grazed in the morning and were kept in pen until evening. The lambing periods started in the second half of February and ended in the first decade of April. Lambs were weaned from ewes in 2-4-months old age, but not later June 15. At all times, outside the insemination campaign, ewes and adult rams were kept separate in pens that were remote at a distance of at least 50 meters from each other. The weighing of animal was carried out at the end of May-beginning of June (in the time or after the weaning) and in the third decade of August (before start of the insemination campaign). Relative change of weight (the change of weight, $\mathrm{ChW}_{i}$ ) calculated was calculated as difference between the weight in May and August, divided by the weight in May and multiplied by 100 .

\section{Heat detection and animal insemination.}

The insemination campaigns were carried out in two sequential steps: at the first stage after heat detection ewes were inseminated one time in the morning with fresh sperm of tested rams - the period of "controlled insemination", at the second 
stage rams were joined with flock to free mating with ewes, which remained infertile, - the period of "uncontrolled mating". Heat in ewes was detected with use of ram-teasers with the tied aprons.

Insemination campaigns were began in September: in 2011 - in 20, in 2012 - 19, 2013 - 21, 2014 - 9, 2015 - 10 and 2016 - in 15 September. Duration of period of "controlled insemination" varied from 31 to 37, of "uncontrolled mating" - from 12 to 15 days.

Estimation of renewal of sexual activity and reproduction traits. Sexual activity and reproduction of all the ewes were evaluated with the indices of the (seasonal) renewal of sexual activity, which were developed for individual animals, $\mathrm{IH}_{i}, \mathrm{IHT}_{i}, \mathrm{ICT}_{i}$ and $\mathrm{IL}_{i}$, and traits, which are traditionally used for evaluation of reproduction of animal groups, $-\mathrm{E} \%, \mathrm{~F} \%, \mathrm{Fm} \%$ and $\mathrm{Pf}$. Value of the indices of each ewe and the reproduction traits of animal groups were identified as follows:

- $\mathrm{IH}_{i}$ - index of heat - was equated to 1 , if ewe showed heat during period of "controlled insemination" or lambed after "uncontrolled mating", and $\mathrm{IH}_{i}=0$, if both the animal didn't showed heat and didn't lambed after "uncontrolled mating";

- $\mathrm{IHT}_{i}$ — index of heat time - was equated to 1 , if ewe showed the first heat during the first 20 days of the insemination campaign; $\mathrm{IHT}_{i}=2$, if ewe showed the first heat after 20 days from beginning of the insemination campaign; $\mathrm{IHT}_{i}=3$, if ewe didn't show heat during period of "controlled insemination" but lambed after "uncontrolled mating"; IHT $=4$, if ewe both didn't show heat during "controlled insemination" and didn't lambed after "uncontrolled mating";

- $\mathrm{ICT}_{i}$ - index of conception time was equated to 1 , if ewe fertilized in the first heat, $\mathrm{ICT}_{i}=2$, if one fertilized in the second heat, $\mathrm{ICT}_{i}=3$, if animal fertilized in the third or fourth heat, $\mathrm{ICT}_{i}=4$, if ewe remained barren;

- $\mathrm{IL}_{i}$ - index of lambing — was equated to 1 , if ewe lambed single, 2 - lambed twins, 3 triplets or more lambs, 0 - if ewe did not lambed;

- $\mathrm{E} \%$ - portion of ewes in oestrus was calculated by dividing the number of ewes, which showed heat during period of "controlled insemination", for the total number of animals and multiplying by 100 ;
- F\% - fertility - was calculated by dividing the number of ewes lambed for the total number of animals and multiplying by 100 ;

- Fm\% - fecundity - was calculated by dividing the number of all the received lambs for the total number of animals and multiplying by 100 ;

- Pf - prolificacy — was calculated by dividing the number of all the received lambs for the total number of lambed ewes.

Statistical analysis. To calculate the correlation indices and for the regression analysis, two types of data were used. The firsts were the data of the age subgroups. To receive the age subgroup data the values of the individual indices and Pf of each ewe were grouped according to the number of full years in the numerical value of ewe's age at the beginning of the insemination campaign - 1,2, 3 , $4,5,6,7$ and $\geq 8$ years. Then, for the each subgroup, the mean values of the indices and Pf were calculated by averaging of individual values of ewes. Also, for each subgroup, the $\mathrm{E} \%, \mathrm{~F} \%$ and $\mathrm{Fm} \%$ were calculated. Total number (n) of data for each indices and traits was equal 48 ( 8 age subgroups for each 6 years).

The second type of data was the annual data. These data were obtained by averaging of data of 8 age subgroups, which were received within each 6 years $(\mathrm{n}=6$ for each indices, traits and climatic parameters).

Results were statistically calculated with the common accepted ANOVA algorithms with use of the mathematical tools of the Excel program of Microsoft Office package. The functional relationship between the indices and the reproductive traits was investigated by plotting and analysing of the graphs, by calculation of the regression equation (in figures it was showed as a trend line) and by evaluation of empirical correlation index (R). According to a previous estimate, the regression equation was best described by the polynomial. We limited ourselves to calculating polynomials of the $2^{\text {nd }}$ degree, which had the view $y=a x^{2}+b x+c$, where $a, b, c$ are the coefficients of the polynomial, $x$ and $y$ - analysed index and trait. The values of $a$, $b$ and $c$ are showed in the results section. It should be noted that the use of the $3^{\text {rd }}$ grade polynomial did not be changed the character of the relationship between indices and features, although in some cases had showed better approximation. The em- 
pirical correlation index $(\mathrm{R})$ between indices and traits was calculated after the analytical smoothing of data by the method of finite difference with use the services of the site math.semestr.ru. The correlation relations between the indices and climatic parameters were estimated by calculation of the coefficient of the linear correlation (r) with help of an additional module "Data Analysis" of the program "Excel". Probability (P) of the coefficients of the regression polynomials was determined by the Fisher criterion $(\mathrm{F})$, of the coefficients and indices of correlation - by the Student criterion $\left(\mathrm{t}_{\mathrm{d}}\right)$.

Designations used. The "2011-2012" mark means that insemination of ewes was carried out in 2011 and their lambing took place in 2012. For analyse the correlation between indices/traits and climatic parameters the data of year of insemination were used.

\section{Results and discussion}

It is known that sexual activity and fertility of animals, which belong to the same breed and kept under identical conditions, are significantly affected by the age and the weight at time of insemination $[1,16]$. So, in the first stage how age, weight and its change correlate with each other were analysed.

\section{Relationship between the age and the} weight of animals. Fig. 1a shows the mean body weight of ewes of the different age subgroups before insemination in the different years. For visual differentiation, data are presented in the form of lines. The bold solid line here and further shows the value of corresponding trait, which was obtained by averaging of values of the identical age subgroups of all 6 years. In all the years the weight of animals of the 1- and 2-year-old age subgroups yielded to others. It was noted tendency of the largest value of the mean weight in 5-6-year-old animals and its decrease in more aged ewes.

The weight of animals depends on their size and fatness. Instead of fatness the relative change of ewes weight at period preceding the insemination campaign (May-August) was analysed (fig. 1b). In 1-3-year-old animals the body weight tended to increase (indicator of the weight change was higher 0 ), while in the most age old ewes ( 8 and more years) - to decrease.
It should be noted that in 2012 in all the age subgroups the weight in August was smaller than in May. This may be due to the highest average daily air temperature at May-June of this year among 6 ones analysed. But previously observed tendency had been preserved.

Apparently, dependence of the weight from the age was non-linear and in $>3$-year-old ewes difference in the weight between the subgroups almost disappeared. Thus, in 3-7-year-old animals the age became the main difference between ewes. Because winter-spring lambing, only the difference in the age between ewes is discrete. Therefore, the use of age as a parameter according to which the indices and traits were grouped is justified.

Relationship between the indices of renewal and the age, the weight and the change of weight. At next stage, using data of the age subgroups ( $\mathrm{n}=48$ for each indicator), the degree of the correlation relationship (the correlation index $\mathrm{R}$ ) between the indices of renewal and the age, the weight and the weight change were analysed. Results have been presented by the graphics.

\section{Relation with the age of ewe at insemina-}

tion. The mean $\mathrm{IH}_{i}$ index (fig. 2a) showed a gradual increase with a rise of a number of the age subgroup from 1 to 6 and expansive decrease in the most aged animals ( 8 and more years). It must be reminded that according to established rules the $\mathrm{IH}_{i}$ index was different from 0 not only for ewes that showed visual signs of heat during "controlled insemination", but also for ones, which lambed after "uncontrolled mating", and, thus, had heat. The mean $\mathrm{IHT}_{i}$ index (fig. 2b) was slightly different within the 2-7-year-old age subgroups and was the highest in the youngest and oldest animals. Because the increase of the $\mathrm{IHT}_{i}$ index is due to a later displaying of the first heat, high value of this index shows that in ewe lambs and $\geq 8$-year-old animals the appearance of the first heat is essentially delayed.

The graphics of the mean $\mathrm{ICT}_{i}$ index had a U-shaped view with a minimum in animals with a numbers of the age subgroup from 3 to 6 (fig. 2c). By the trend of the index change it may be assumed that, despite the same rate of display of the first heat (fig. 2b), 3-6-year-old animals are fertilized faster than 2- and $\geq 7$-year-old. Consequently, the quality of ovulation in 2- and 7-year-old animals is worse than of 3-6-year-old ones, despite the 

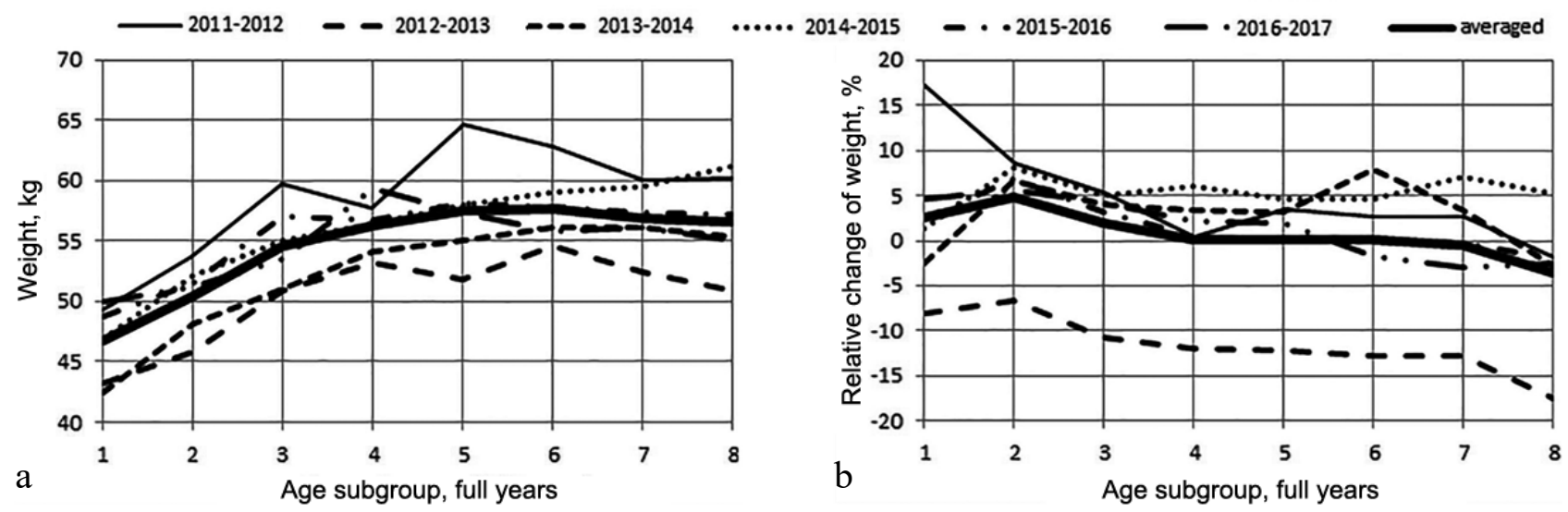

Fig. 1. The mean weight (a) and the weight change (b) before insemination for ewes of the different age subgroups in the different years

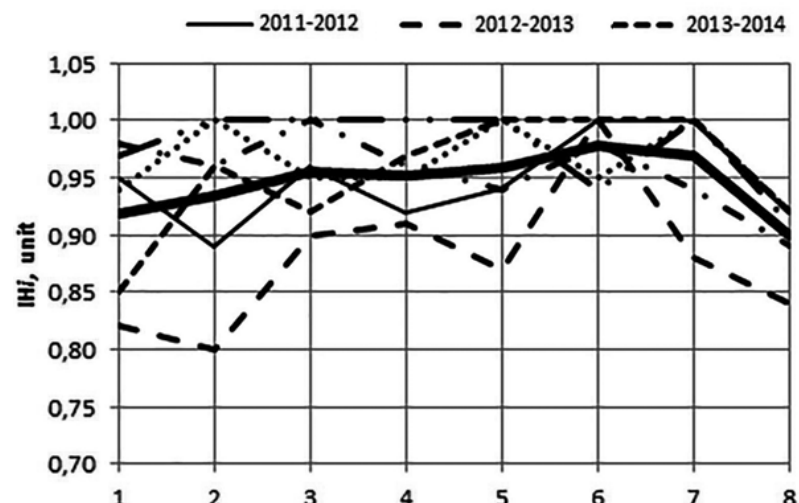

a

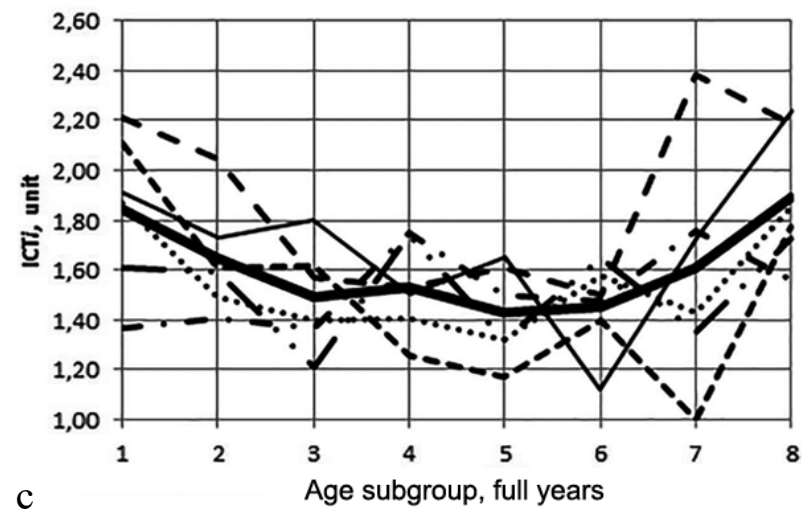

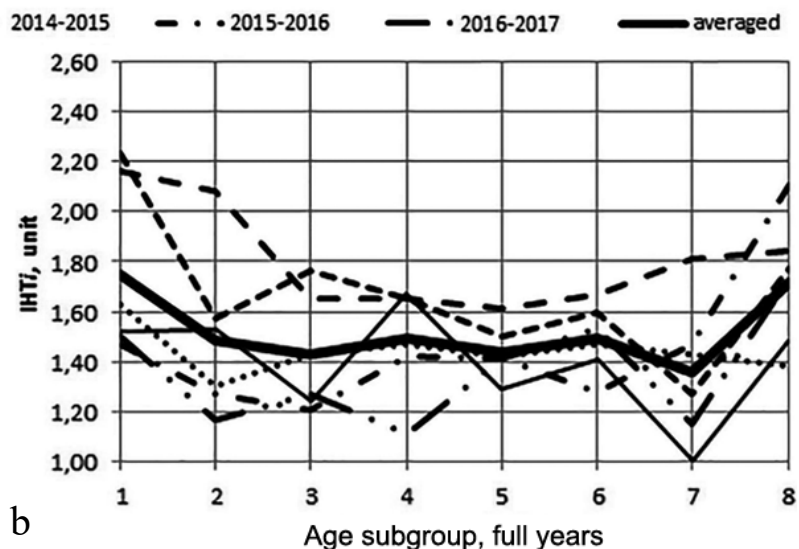

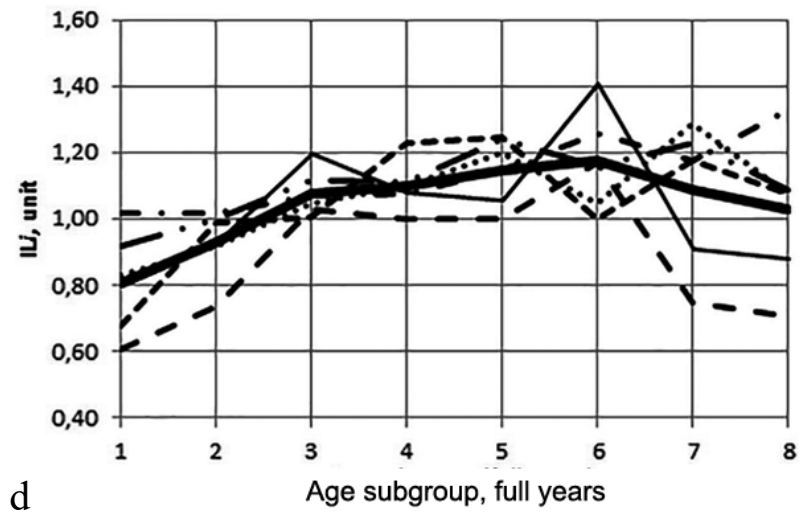

Fig. 2. Values of the $\mathrm{IH}_{i}(\mathrm{a}), \mathrm{IHT}_{i}(\mathrm{~b}), \mathrm{ICT}_{i}(\mathrm{c})$ and $\mathrm{IL}_{i}(\mathrm{~d})$ indices of ewes of the different age subgroups in the different years

slight difference in the showing of heat between these subgroups (fig. 2b). The youngest and oldest animals had the worst success of fertilization in the first heat. The mean $\mathrm{IL}_{i}$ index showed a gradual increase with an add-on in an age subgroup number from 1 to 3, slowing down of growth with change of a number from 3 to 6 and following almost linear decrease (fig. 2c). It should be noted that dynamics of change of the $\mathrm{IL}_{i}$ index completely coincided with such in the fertility trait (unpublished) that does the $\mathrm{IL}_{i}$ index an individual indicator of the fertility for individual animal.

All the coefficients of regression equations and the correlation indices were reliable $\left(F>F_{c r}\right.$, $t_{d}>t_{d c r}$ (table 1).

\section{Relation with the weight at beginning} of insemination. Relationships between the weight (W) of ewe before insemination and the indices of renewal were non-linear (fig. 3). As in the previous ones, all the coefficients of regression 
equations and the correlation indices were reliable $\left(F>F_{c r}, t_{d}>t_{d c r}\right)$ (table 2). However, with due regard for detected dependence of the indices from the age (fig. 2) and relationship of the age with the weight (fig. 1a), it is quite obvious that dependence of the indices from the weight in ewes of the different age subgroups must be different too. To confirm this, the correlation indices were calculated separately for two ewe groups - the $1^{\text {st }}$ includes values of 1-2-year-old animals $(n=12)$, the $2^{\text {nd }}-3$ and more-year-old ones $(\mathrm{n}=36)$. Results are shown in table 3.

As can be seen, in young animals $(<3$ full years) correlation between the weight and all the indices of renewal was significantly high $(R>0.7)$, while in older ages - between weak and noticeable ( $R$ between 0.1 and 0.7 ). In younger ewes the increase in the weight were accompanied by an increase in the $\mathrm{IH}_{i}$ and the $\mathrm{IL}_{i}$ indices and a decrease in the $\mathrm{IHT}_{i}$ and the $\mathrm{ICT}_{i}$. This is evidence of acceleration of showing of heat and improvement of success of the first insemination with an increase of the weight. In more aged ewes with increase of the weight the $\mathrm{IH}_{i}$ index didn't almost change and the $\mathrm{IHT}_{i}$ linearly decreased. The $\mathrm{ICT}_{i}$ index began to increase and the $\mathrm{IL}_{i}$ slightly decreased after overcoming $58 \mathrm{~kg}$ weight. The latter suggests that overgrowth of the average weight of ewes of this breed is accompanied by their obesity, which that negatively affects the ability of ewes to become pregnant. Connection of excessive mass of subcutaneous fat with reduced fertility in sheep was also noted by [16].

Relation with the weight change. As well as for the weight, relationship between the weight change and the indices of renewal was non-linear (fig. 4). With increasing of the weight change the appearance of heat (fig. 4a) and rate of this event (fig. 4b) had improved. As well as for the weight, with over growth of the weight change the ability to become pregnant in the first heat (fig. 4c) and the $\mathrm{IL}_{i}$ index (fig. 4d) worsened too.

Significance of the calculated coefficients of regression equations and the correlation indices were reliable (table 4). As before, because strength of correlation could be significantly adjusted by existing dependence of the weight from ewe age (fig. 1), the correlation indices were calculated separately for the different age categories (table 5).
Coefficients of the $2^{\text {nd }}$ level polynomials of the regression equation and the correlation indices $(R)$ calculated for relations between the age (Ag) and the indices of renewal

\begin{tabular}{|l|c|c|c|c|c|c|}
\hline $\begin{array}{c}\text { Researched } \\
\text { relation }\end{array}$ & $a$ & $b$ & $c$ & $F$ & $R$ & $t_{d}$ \\
\hline $\mathrm{IH}_{i}(\mathrm{Ag})$ & -0.004 & 0.039 & 0.876 & 3.71 & 0.3762 & 2.75 \\
\hline $\mathrm{IHT}_{i}(\mathrm{Ag})$ & 0.022 & -0.207 & 1.892 & 4.02 & 0.3895 & 2.87 \\
\hline $\mathrm{ICT}_{i}(\mathrm{Ag})$ & 0.034 & -0.309 & 2.131 & 8.71 & 0.5282 & 4.22 \\
\hline $\mathrm{IL}_{i}(\mathrm{Ag})$ & -0.019 & 0.199 & 0.625 & 15.98 & 0.6444 & 5.72 \\
\hline
\end{tabular}

Note: $-\mathrm{n}=48$ for each trait, $\mathrm{F}_{\mathrm{cr}}=3.20, \mathrm{t}_{\mathrm{dcr}}=2,02$.

Coefficients of the $2^{\text {nd }}$ level polynomials of the regression equation and the correlation indices $(R)$ calculated for relations between the weight $\left(W_{i}\right)$ and the indices of renewal

\begin{tabular}{|l|c|c|c|c|c|c|}
\hline $\begin{array}{c}\text { Researched } \\
\text { relation }\end{array}$ & $a$ & $b$ & $c$ & $F$ & $R$ & $t_{d}$ \\
\hline $\mathrm{IH}_{i}\left(\mathrm{~W}_{i}\right)$ & -0.001 & 0.055 & -0.651 & 9.87 & 0.5916 & 4.98 \\
\hline $\mathrm{IHT}_{i}\left(\mathrm{~W}_{i}\right)$ & 0.002 & -0.228 & 8.471 & 14.33 & 0.6238 & 5.41 \\
\hline $\mathrm{ICT}_{i}\left(\mathrm{~W}_{i}\right)$ & 0.003 & -0.371 & 12.061 & 6.91 & 0.4848 & 3.76 \\
\hline $\mathrm{IL}_{i}\left(\mathrm{~W}_{i}\right)$ & -0.001 & 0.180 & -4.420 & 26.48 & 0.7353 & 7.36 \\
\hline
\end{tabular}

Note: $-\mathrm{n}=48$ for each trait, $\mathrm{F}_{\mathrm{cr}}=3.20, \mathrm{t}_{\mathrm{dcr}}=2.02$.

Table 3

Indices of correlation relationship $(R)$ between weight and indices of renewal for animals of different ages

\begin{tabular}{|l|c|c|c|c|}
\hline \multirow{2}{*}{$\begin{array}{c}\text { Researched } \\
\text { relation }\end{array}$} & \multicolumn{4}{|c|}{ Animal age (full years) } \\
\cline { 2 - 5 } & $1-2$ years $(\mathrm{n}=12)$ & \multicolumn{2}{|c|}{$\geq 3$ years $(\mathrm{n}=36)$} \\
\cline { 2 - 5 } & $R$ & $t_{d}$ & $R$ & $t_{d}$ \\
\hline $\mathrm{IH}_{i}\left(\mathrm{~W}_{i}\right)$ & 0.7738 & 3.86 & 0.5773 & 4.12 \\
\hline $\mathrm{IHT}_{i}\left(\mathrm{~W}_{i}\right)$ & 0.9275 & 7.85 & 0.5461 & 3.80 \\
\hline $\mathrm{ICT}_{i}\left(\mathrm{~W}_{i}\right)$ & 0.8157 & 4.46 & 0.2707 & 1.64 \\
\hline $\mathrm{IL}_{i}\left(\mathrm{~W}_{i}\right)$ & 0.8546 & 5.20 & 0.5020 & 3.38 \\
\hline
\end{tabular}

Note: $-t_{d c r}=2.23$ for $\mathrm{n}=12, t_{d c r}=2.04$ for $\mathrm{n}=36$.

Table 4

Coefficients of $2^{\text {nd }}$ level polynomials of regression equation and correlation indices $(R)$

calculated for relations between the weight change $\left(\mathrm{WCh}_{i}\right)$ and the indices of renewal

\begin{tabular}{|l|c|c|c|c|c|c|}
\hline $\begin{array}{c}\text { Researched } \\
\text { relation }\end{array}$ & $a$ & $b$ & $c$ & $F$ & $R$ & $t_{d}$ \\
\hline $\mathrm{IH}_{i}\left(\mathrm{WCh}_{i}\right)$ & -0.0001 & 0.004 & 0.948 & 10.99 & 0.5729 & 4.74 \\
\hline $\mathrm{IHT}_{i}\left(\mathrm{WCh}_{i}\right)$ & 0.0004 & -0.018 & 1.516 & 7.12 & 0.4902 & 3.81 \\
\hline $\mathrm{ICT}_{i}\left(\mathrm{WCh}_{i}\right)$ & 0.0011 & -0.013 & 1.572 & 5.73 & 0.4507 & 3.42 \\
\hline $\mathrm{IL}_{i}\left(\mathrm{WCh}_{i}\right)$ & -0.001 & 0.003 & 1.090 & 5.80 & 0.4528 & 3.44 \\
\hline
\end{tabular}

Note: $-\mathrm{n}=48$ for each trait, $\mathrm{F}_{\mathrm{cr}}=3.20, \mathrm{t}_{\mathrm{dcr}}=2.02$.

In young animals the relationships between the weight change and the indices were high, while in older ewes - between moderate and noticeable. 

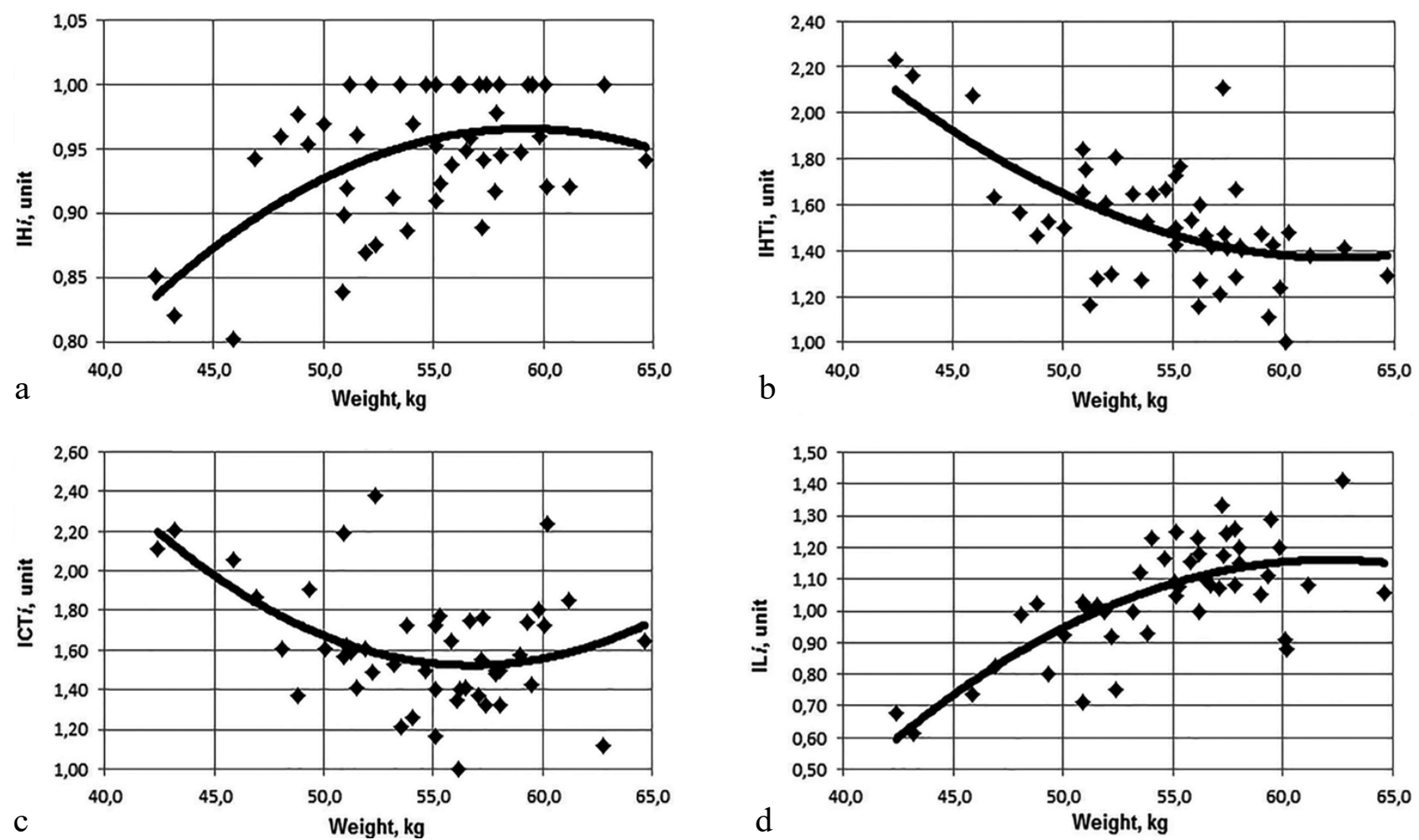

Fig. 3. Graphics of data and trend lines for pairs $\mathrm{W}_{i}-\mathrm{IH}_{i}(\mathrm{a}), \mathrm{W}_{i}-\mathrm{IHT}_{i}(\mathrm{~b}), \mathrm{W}_{i}-\mathrm{ICT}_{i}(\mathrm{c})$ and $\mathrm{W}_{i}-\mathrm{IL}_{i}(\mathrm{~d})$.
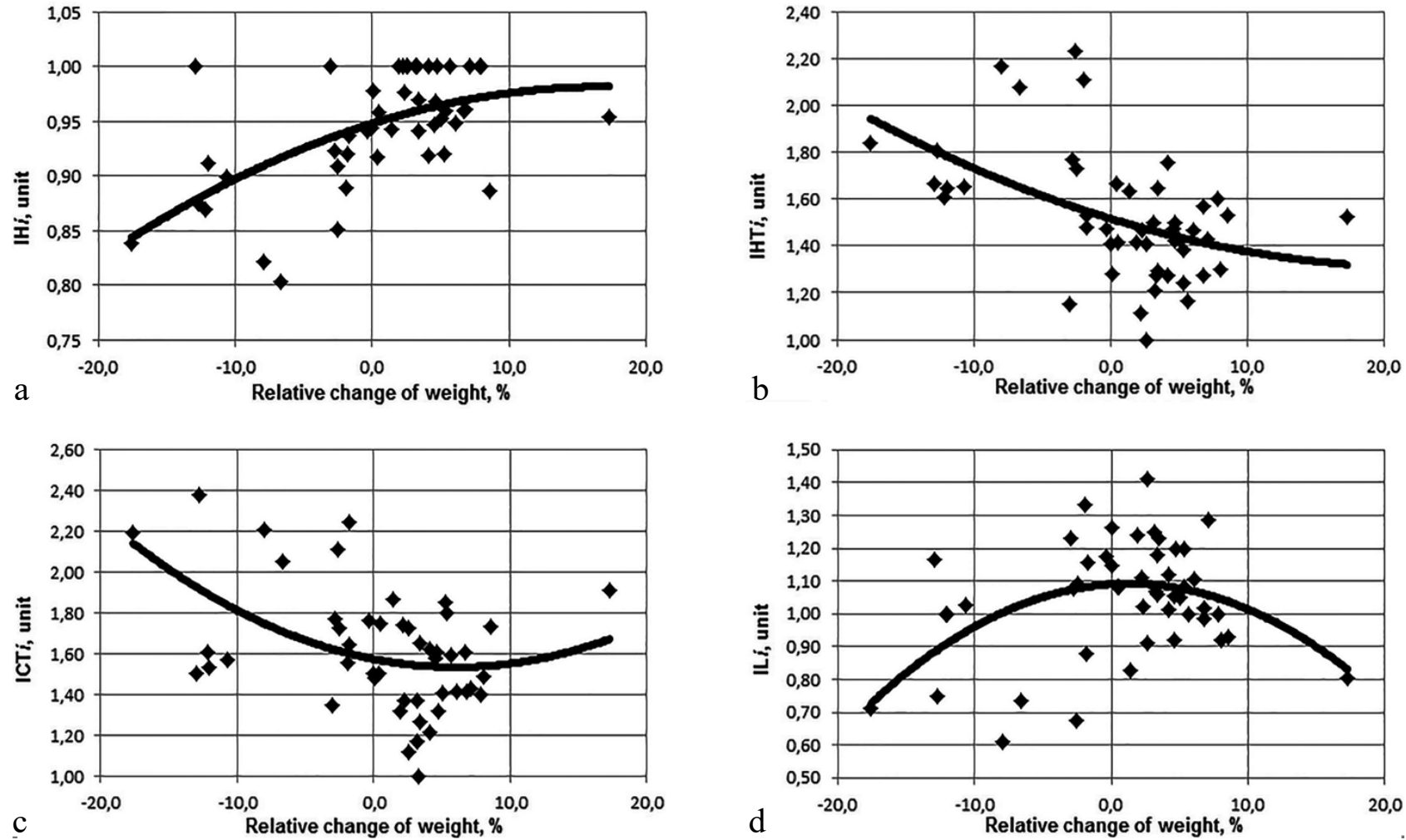

Fig. 4. Graphics of data and trend lines for pairs $\mathrm{WCh}_{i}-\mathrm{IH}_{i}(\mathrm{a}), \mathrm{WCh}_{i}-\mathrm{IHT}_{i}(\mathrm{~b}), \mathrm{WCh}_{i}-\mathrm{ICT}_{i}(\mathrm{c})$ and $\mathrm{WCh}_{i}-\mathrm{IL}_{i}(\mathrm{~d})$.

It is interesting that in young ewes a relative change of weight in range from minus 20 to plus 10 percent promoted increase in the indices $\mathrm{IH}_{i}$ and the $\mathrm{IL}_{i}$ and the decrease in the $\mathrm{IHT}_{i}$ and the $\mathrm{ICT}_{i}$, in range from plus 10 to plus 20 percent - a slight decrease in the $\mathrm{IH}_{i}$ and the $\mathrm{IL}_{i}$ and also an increase in the $\mathrm{IHT}_{i}$ and the $\mathrm{ICT}_{i}$ indices. In more old animals the cases of relative change more than $12 \%$ were not observed. 


\begin{tabular}{|c|c|c|c|c|}
\hline \multicolumn{5}{|c|}{$\begin{array}{l}\text { Indices of correlation relations }(R) \\
\text { between the weight change }\left(\mathrm{WCh}_{i}\right) \\
\text { before insemination and the indices of renewal } \\
\text { for animals of different ages }\end{array}$} \\
\hline \multirow{3}{*}{$\begin{array}{l}\text { Researched } \\
\text { relation }\end{array}$} & \multicolumn{4}{|c|}{ Animal age (full years) } \\
\hline & \multicolumn{2}{|c|}{$1-2$ years $(n=12)$} & \multicolumn{2}{|c|}{$\geq 3$ years $(n=36)$} \\
\hline & $R$ & $t_{d}$ & $R$ & $t_{d}$ \\
\hline $\mathrm{IH}_{i}\left(\mathrm{WCh}_{i}\right)$ & 0.8603 & 5.34 & 0.6248 & 4.67 \\
\hline $\mathrm{IHT}_{i}\left(\mathrm{WCh}_{i}\right)$ & 0.8683 & 5.54 & 0.4960 & 3.33 \\
\hline $\mathrm{ICT}_{i}\left(\mathrm{WCh}_{i}\right)$ & 0.8470 & 5.04 & 0.4679 & 3.09 \\
\hline $\mathrm{IL}_{i}\left(\mathrm{WCh}_{i}\right)$ & 0.8752 & 5.72 & 0.5809 & 4.16 \\
\hline
\end{tabular}

Note: $-t_{d c r}=2.23$ for $\mathrm{n}=12$ and $t_{d c r}=2.04$ for $\mathrm{n}=36$.

In these ewes with an increase in the weight change the $\mathrm{IHT}_{i}$ and the ICT $i$ indices almost linearly diminished and the $\mathrm{IH}_{i}$ increased, the $\mathrm{IL}_{i}$ showed a peak with zero change of weight.

Thus, the indices of renewal of sexual activity showed relationship with the age, the weight and the weight change. Additionally, the degree of relationship between the indices and the weight and its change in young (1-2-year-old) animals was significantly high $(R>0.7)$.

Relationship between the indices of renewal and fertility, fecundity and prolificacy. It can't be said about the expedience and comprehension of the proposed indices without analysis of their relations with each other and with traditional reproductive traits.

The pair of "IHT $-\mathrm{CT}_{i}$ " is the most significant for total assessment of quality of the renewal of sexual activity, because it links the rate of display of heat with success of insemination. Fig. 5a shows relation between the $\mathrm{IHT}_{i}$ and the $\mathrm{ICT}_{i}$ indices. As can be seen, there is the noticeable correlation between indices $(R=0.5250)$. Also, there is a minimum for the $\mathrm{ICT}_{i}$ in the $\mathrm{IHT}_{i}=1.3$ that became more significant when using the $3^{\text {rd }}$ degree polynomial $(R=0.5612)$. Presence of this minimum indicates that in the first days of insemination campaign the capability of ewes to become pregnant is slightly reduced. The last may be caused by deteriorated quality of a certain part of ovulated ova.

Fig. 5b shows character of link between the $\mathrm{IHT}_{i}$ index and E\%, fig. $5 \mathrm{c}$ - with F\%, fig. 5dFm\% and fig. 5e - with Pf. Fig. 5f-h display links between the $\mathrm{ICT}_{i}$ and $\mathrm{F} \%$, $\mathrm{Fm} \%$, Pf.

The IHT $_{i}$ index with a high degree negatively correlated with $\mathrm{E} \%$. The last means that the later ewes began to show heat, the less animals show heat during period of "controlled insemination" (fig. 5b). The IHT index reversibly correlated with $\mathrm{F} \%$ and $\mathrm{Fm} \%$ (fig. $5 \mathrm{c}$ and fig. 5d) with a noticeable level. It is interesting that in pair $\mathrm{IHT}_{\bar{i}}$ $\mathrm{Fm} \%$ maximum value of the $\mathrm{Fm} \%$ index was observed at the $\mathrm{IHT}_{i}=1.3$.

Relationship between the $\mathrm{ICT}_{i}$ index and $\mathrm{E} \%$ was not studied with due regard for independent nature of these indicators. The ICT index showed an almost functional $(R>0.9)$ relationship with $\mathrm{F} \%$ (fig. 5f) and high $(R>0.7)$ with Fm\% (fig. 5g).

The $\mathrm{IHT}_{i}$ and $\mathrm{ICT}_{i}$ indices showed a weak relationship with Pf (fig. 5e and fig. 5h). This indicates that prolificacy is more susceptible to influence of factors not related to rate of display of the first heat and an ordinal number of heat, which is completed by fertilization. However, it should be understood that success of insemination and hence value of the $\mathrm{ICT}_{i}$ index are determined not only by amount and quality of ovulated ova, but also by readiness of genital tract, its ability to support sperm movement. Absence of the close relationship between the $\mathrm{ICT}_{i}$ index and Pf may partly indicate about retardation of the complete recovery of the proliferative processes in genital tract from analogous ones in ovaries.

The calculated level of the coefficients of regression equations and functional relationship of the indices of renewal of sexual activity with reproductive traits was reliable for most pairs $\left(F>F_{c r}\right.$, $\left.t_{d}>t_{d c r}\right)($ table 6).

Table 6

Coefficients of the $2^{\text {nd }}$ level polynomials of regression equation and the correlation indices $(R)$ calculated for relations between the indices of renewal and the reproductive traits

\begin{tabular}{|l|c|c|c|c|c|c|}
\hline $\begin{array}{c}\text { Researched } \\
\text { relation }\end{array}$ & $a$ & $b$ & $c$ & $F$ & $R$ & $t_{d}$ \\
\hline $\mathrm{ICT}_{i}\left(\mathrm{IHT}_{i}\right)$ & 0.613 & -1.441 & 2.341 & 8.57 & 0.5253 & 4.18 \\
\hline${\mathrm{E} \%\left(\mathrm{IHT}_{i}\right)}$ & 0.794 & -31.886 & 130.384 & 28.64 & 0.7484 & 7.64 \\
\hline${\mathrm{F} \%\left(\mathrm{IHT}_{i}\right)}^{-15.624}$ & 28.130 & 79.323 & 12.33 & 0.5951 & 5.02 \\
\hline${\mathrm{Fm} \%\left(\mathrm{IHT}_{i}\right)}$ & -40.080 & 100.510 & 47.220 & 7.57 & 0.5017 & 3.93 \\
\hline $\mathrm{Pf}\left(\mathrm{IUO}_{i}\right)$ & -0.321 & 0.988 & 0.493 & 1.60 & 0.2574 & 1.81 \\
\hline $\mathrm{F} \%\left(\mathrm{ICT}_{i}\right)$ & -13.138 & 12.443 & 100.136 & 156.14 & 0.9350 & 17.91 \\
\hline Fm\% $\left(\mathrm{ICT}_{i}\right)$ & -15.016 & 6.516 & 134.420 & 31.78 & 0.7650 & 8.06 \\
\hline $\mathrm{Pf}\left(\mathrm{ICT}_{i}\right)$ & -0.012 & -0.019 & 1.295 & 0.42 & 0.1358 & 0.92 \\
\hline
\end{tabular}

Note: $-\mathrm{n}=48$ for each trait, $\mathrm{F}_{\mathrm{cr}}=3.20, \mathrm{t}_{\mathrm{dcr}}=2.02$.

Relations the indices of renewal and reproduction traits with climatic parameters. In analysis the annual data are used. Level of relationship was 

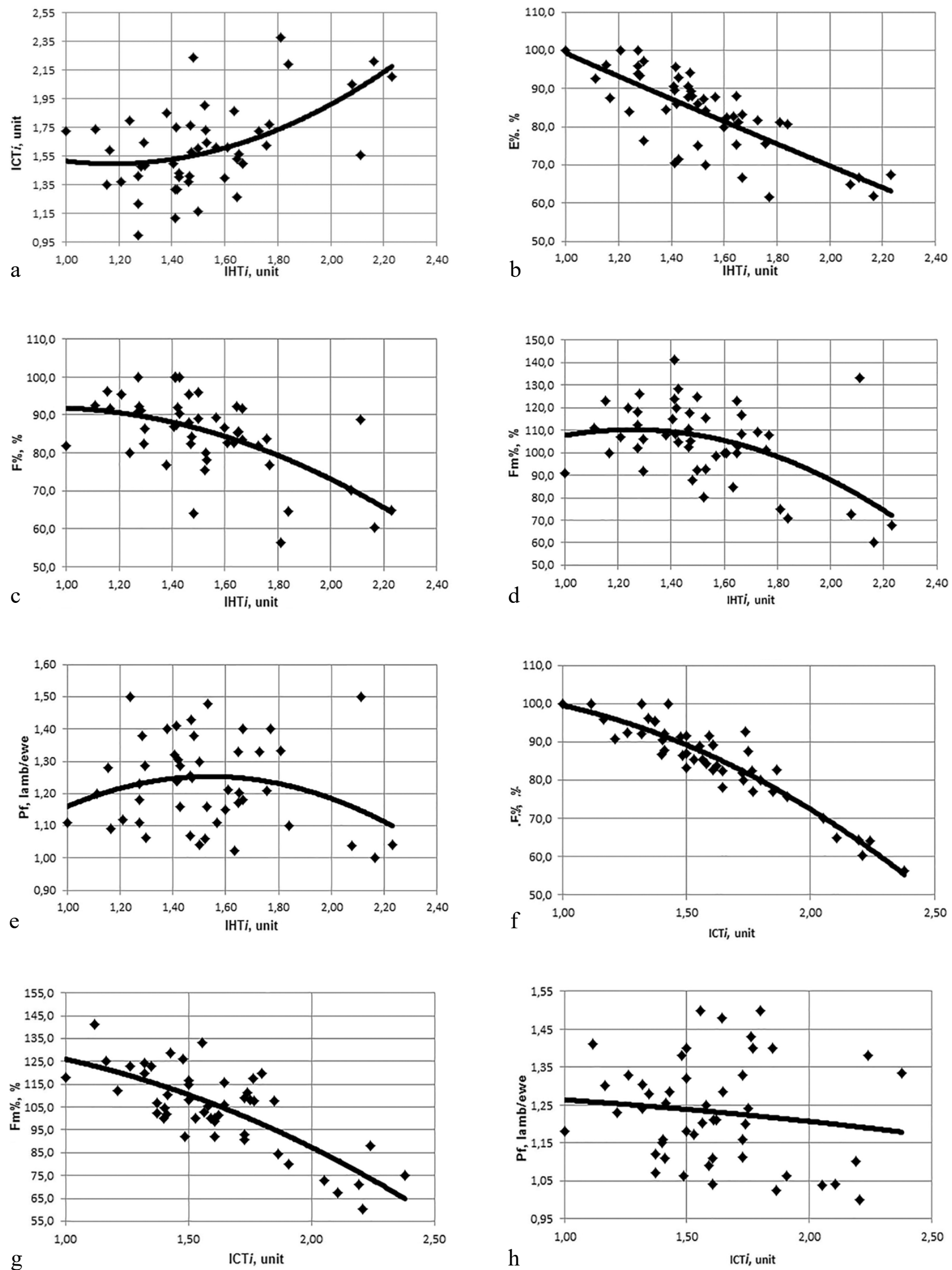

Fig. 5. Graphics of data and trend lines for pairs $\mathrm{IHT}_{i}-\mathrm{ICT}_{i}$ (a), $\mathrm{IHT}_{i}-\mathrm{E} \%$ (b), $\mathrm{IHT}_{i}-\mathrm{F} \%$ (c), $\mathrm{IHT}_{i}-\mathrm{Fm} \%$ (d), $\mathrm{IHT}_{i}-\mathrm{Pf}(\mathrm{e})$, $\mathrm{ICT}_{i}-\mathrm{F} \%$ (f), $\mathrm{ICT}_{i}-\mathrm{Fm} \%$ (g) and $\mathrm{ICT}_{i}-\mathrm{Pf}(\mathrm{h})$ 
calculated with assuming linear character of links $(r)$. The increase in average air temperature negatively affected almost all the indicators. The most significant relations were noted with parameters in May and July (table 7). As can be seen, an increase in mean temperature in May and June coincided with an increase in the $\mathrm{IHT}_{i}$ index and a decrease in portion of ewes showed heat (E\%). Thus, high air temperature in May delayed the show of heat in September. Relationship between the $\mathrm{IH}_{i}$ index and temperature in May was not reliable. It may be supposed that negative influence of May-June conditions on manifestation of heat could be partially neutralized by other factors. Temperature in July significantly affected ability of ewes to became pregnant during the first heat $\left(\mathrm{ICT}_{i}\right)$, lambing $\left(\mathrm{IL}_{i}\right)$, fertility $(\mathrm{F} \%)$ and fecundity (Fm\%). Prolificacy (Pf) was the most negatively affected by average temperature in May and at the entire period from May to September.

The total rainfall amount, on occasion, showed a noticeable level $(0.5<r<0.7)$ of correlation with the indices of renewal and reproductive traits but did not reached the reliable level, therefore, it is impossible to claim the established influence of this parameter on reproduction (table 8). The possible cause of the latter may be that the research was carried out in domestic sheep, which in the summer months, in addition to grazing, were provided green feed and, accordingly, the quality of its' food did not depend on the weather. It is interesting that prolificacy of ewes negatively correlated with the rainfall amount in August. It is possible to assume that a negative effect was caused by excessive amount of phytoestrogens, which were contained the young grass stimulated by rain.

The average humidity in June showed significant positive relationship with amount of ewes, which showed heat during the insemination campaign, similar parameter in July - with prolificacy (table 9).

The introduction of modern intensive technologies of sheep breeding raised the problem to reduce the influence of seasonality on sexual function of animals. One way of achieving is to cross the breeds that are characterized by different duration of anestrous period [11, 14]. A significant disadvantage of this approach is change of breed of animal. In our opinion, one of possible breeding methods may be the step-by-step narrowing of boundaries of the anestrous period by careful removal of ewes, which delay a natural display of sexual activity. In this case it is necessary to know how quickly and fully the individual animal exhibits heat, what influences it and whether this feature is repeated. With use of indicators that are traditionally used to evaluate sheep reproductive performance, such analysis is impossible. The developed indices will allow such an assessment.

Among the developed the most significant indices, in our opinion, are the $\mathrm{IHT}_{i}$ and the $\mathrm{ICT}_{i}$ indices, which are linked to certain time characteristics. In particular, the $\mathrm{IHT}_{i}$ index characterizes how quickly ewe shows heat. Its increase is caused by more late response. It can be argued that interval chosen for the $\mathrm{IHT}_{i}$ ranging (20 days) is not physiologically justified. In particular, the sexual cycle in sheep of Ascanian Merino breed is equal 8-18 days. However, fact that at the beginning of insemination campaign the introduction of ram in flock can stimulate a "quiet heat" in a certain portion of ewes $[4,15]$ was taken into account. It is known that this ovulation occurs 2-4 days after beginning of contact [6] with the appearance of following normal heat after 16-18 days. In order to exclude such animals from those that delay the manifestation of the sexual activity, the 20-day term was chosen as marginal.

It may be noticed that, to character the quality of the renewal of sexual activity, the time interval between start of insemination campaign and heat may be used [9]. But this parameter is not defined in ewes, which do not show heat during period of "controlled insemination", but are lambed after "uncontrolled mating". In addition, such method doesn't take into account the possibility of existence the first heat that not ended by fertilization.

Other significant index is the $\mathrm{ICT}_{i}$ index, which coordinates with ordinal number of heat that ended by fertilization. Of course, in some cases reasons of absence of fertilization may be the low quality of sperm, the immune incompatibility of sperm and ova, poor qualification of operator, etc. However, in case of elimination, minimization or constant influence of these factors, the main cause of difference in value of the $\mathrm{ICT}_{i}$ index becomes the poor quality of ova and inappropriate readiness of uterine epithelium, that is, factors that characterize physiology of concrete ewe. 
Coefficients of linear correlation $(r)$ between average air temperature, the indices of renewal and the reproductive traits

\begin{tabular}{|l|c|c|c|c|c|c|c|c|}
\hline \multirow{2}{*}{ Average air temperature } & \multicolumn{7}{|c|}{ Correlated traits } \\
\cline { 2 - 9 } & $\mathrm{IH}_{i}$ & $\mathrm{IHT}_{i}$ & $\mathrm{ICT}_{i}$ & $\mathrm{IL}_{i}$ & $\mathrm{E} \%$ & $\mathrm{~F} \%$ & $\mathrm{Fm} \%$ & $\mathrm{Pf}$ \\
\hline in May & $-0,6747$ & $\mathbf{0 , 9 3 0 8}$ & 0,2679 & $-0,6384$ & $-0,7951$ & $-0,5260$ & $-0,6382$ & $-0,8085$ \\
\hline in June & $-0,7054$ & $\mathbf{0 , 8 5 4 0}$ & 0,4960 & $-0,6806$ & $\mathbf{- 0 , 8 4 8 0}$ & $-0,6736$ & $-0,6951$ & $-0,6018$ \\
\hline in July & $-0,7376$ & 0,4169 & $\mathbf{0 , 8 6 0 4}$ & $-\mathbf{0 , 8 7 3 8}$ & $-0,5690$ & $\mathbf{- 0 , 8 4 8 4}$ & $\mathbf{- 0 , 8 6 4 0}$ & $-0,6726$ \\
\hline in August & 0,2596 & 0,0768 & $-0,5373$ & 0,3124 & 0,2857 & 0,4717 & 0,2947 & $-0,2535$ \\
\hline in September & $-0,1422$ & $-0,2182$ & 0,3118 & 0,0716 & 0,4855 & $-0,0546$ & 0,0564 & 0,3165 \\
\hline at May-September & $\mathbf{- 0 , 9 0 8 9}$ & $\mathbf{0 , 8 8 1 4}$ & 0,6613 & $-0,7904$ & $-0,5969$ & $-0,7393$ & $-0,8052$ & $\mathbf{- 0 , 8 1 2 6}$ \\
\hline
\end{tabular}

Note: Here and further the bold font means significant $(\mathrm{P}<0.05)$ values, $\mathrm{n}=6$ for each trait.

Table 8

Coefficients of linear correlation $(r)$ between total rainfall amount, the indices of renewal and the reproductive traits

\begin{tabular}{|l|c|c|c|c|c|c|c|c|}
\hline \multirow{2}{*}{\multicolumn{1}{|c|}{ Total rainfall amount }} & \multicolumn{7}{|c|}{ Correlated indicators } \\
\cline { 2 - 10 } & $\mathrm{IO}_{i}$ & $\mathrm{IUO}_{i}$ & $\mathrm{I}_{3} \mathrm{M}_{i}$ & $\mathrm{IG}_{i}$ & $\mathrm{E} \%$ & $\mathrm{~F} \%$ & $\mathrm{Fm} \%$ & $\mathrm{Pf}$ \\
\hline in May & 0,0717 & $-0,2082$ & 0,1287 & 0,0776 & 0,3525 & 0,0594 & 0,0466 & 0,0219 \\
\hline in June & 0,6300 & $-0,6213$ & $-0,5072$ & 0,4234 & 0,5053 & 0,5509 & 0,4432 & 0,0941 \\
\hline in July & 0,0017 & 0,4036 & $-0,3746$ & 0,2031 & $-0,1864$ & 0,1950 & 0,1903 & 0,0809 \\
\hline in August & $-0,3314$ & 0,2132 & 0,4092 & $-0,4424$ & $-0,1298$ & $-0,3486$ & $-0,4594$ & $-0,6110$ \\
\hline in September & 0,5616 & $-0,3633$ & $-0,6150$ & 0,3439 & 0,2104 & 0,5119 & 0,3709 & $-0,0596$ \\
\hline at May-September & 0,4275 & $-0,1977$ & $-0,4929$ & 0,3610 & 0,3690 & 0,4959 & 0,3442 & $-0,1206$ \\
\hline
\end{tabular}

Table 9

Coefficients of linear correlation $(r)$ between average humidity, the indices of revival and the reproductive traits

\begin{tabular}{|l|c|c|c|c|c|c|c|c|}
\hline \multirow{2}{*}{\multicolumn{1}{|c|}{ Average air humidity }} & \multicolumn{7}{|c|}{ Correlated indicators } \\
\cline { 2 - 10 } & $\mathrm{IO}_{i}$ & $\mathrm{IUO}_{i}$ & $\mathrm{I}_{i} \mathrm{M}_{i}$ & $\mathrm{I}_{i}$ & $\mathrm{E} \%$ & $\mathrm{~F} \%$ & $\mathrm{Fm} \%$ & $\mathrm{Pf}$ \\
\hline in May & 0,3488 & $-0,7033$ & 0,0786 & 0,2359 & 0,5913 & 0,1883 & 0,2325 & 0,3373 \\
\hline in June & 0,7256 & $-0,7712$ & $-0,5282$ & 0,8092 & $\mathbf{0 , 9 2 9 1}$ & 0,7503 & 0,7914 & 0,7150 \\
\hline in July & 0,5571 & $-0,4813$ & $-0,4997$ & 0,7535 & 0,5974 & 0,6112 & 0,7377 & $\mathbf{0 , 8 6 7 4}$ \\
\hline in August & 0,0435 & $-0,2761$ & 0,3335 & $-0,1490$ & $-0,0462$ & $-0,2118$ & $-0,1549$ & 0,0807 \\
\hline in September & 0,0449 & 0,3760 & $-0,3129$ & 0,0834 & $-0,3168$ & 0,1218 & 0,0669 & $-0,1131$ \\
\hline at May-September & 0,6169 & $-0,6449$ & $-0,3704$ & 0,6486 & 0,6423 & 0,5509 & 0,6281 & 0,6932 \\
\hline
\end{tabular}

About comprehension of the proposed indices it may not be claimed without the analysis of its relationship with traditional traits. As was shown, relationship between the indices and reproduction traits in most cases is non-linear. At the same time, values of the indices of correlation for relationship between the $\mathrm{IHT}_{i}$ and $\mathrm{ICT}_{i}$ indices from one side and $\mathrm{E} \%, \mathrm{~F} \%$ and $\mathrm{Fm} \%$ from other side lies in the range from moderate to high. This testifies about existence of sufficiently close relationships between the created indices and reproductive traits. In particular, high correlation between the IHT index and $\mathrm{E} \%$ shows that a part of animals with heat becomes the higher that the faster ewes show heat. Relationship between the $\mathrm{ICT}_{i}$ index and $\mathrm{F} \%$ shows that fertility is higher when more number of ewes impregnates in the first heat. This indicates that, in order to increase the total reproductive per- formance, it is necessary to apply methods, which are directed at accelerating the display of heat and improving quality of ova that ovulate at the first heat. Weak correlation of the $\mathrm{IHT}_{i}$ and the $\mathrm{ICT}_{i}$ indices with prolificacy indicates that a number of ovulatory follicles does not depend on the ordinal number of heat and is caused by other factors.

Revealed correlations between the created indices and climatic parameters are no less interesting. The increase in air temperature the most depressively influenced on almost all the indicators that is similar to results of other authors [18]. But what is surprising, it is that the most significant negative effect on the $\mathrm{IHT}_{i}$ index and prolificacy was caused by the increase in temperature not in September, month in which the insemination was carried out, and not in July, which is the hottest month in this area, but at May-June period 
that is distant from beginning of insemination for 3-4 months. Data of table 7 show that one of practical tools to neutralize action of negative factors may be an increase in humidity in places of ewes keeping. A sufficiently high correlation between climatic conditions and the indices of renewal shows that analysis of change of indices can be used to determine the nature of factors, which affect the total reproduction in sheep.

The existing theory of seasonality relates development of anoestrus state in sheep with inhibition of activity of the hypothalamic-pituitary axis, in particular, with the decrease in frequency and amplitude of LH-RH secretion and an increase in sensitivity of certain parts of hypothalamus to negative action of oestrogen [7]. However, it is known that cyclic activity in ewe ovaries continues during anestrous period too [2]. Results of table 2-4 let to suppose that climatic conditions at May-June highly influenced on depth and duration of anestrous behavior, in particular the degree of depressing of hypothalamic site that was later manifested by difference of time of the heat displaying. July's parameters have a greater impact on restoration and amplification of proliferative processes in genital tract and ovaries that is manifested by differences in fertile abilities and prolificacy.

Received results show that the created $\mathrm{IHT}_{i}$ and $\mathrm{ICT}_{i}$ indices definitely reflect quality of showing of sexual activity by ewes during insemination campaign and can be used to assess the influence of various factors on sheep reproduction. It is also important that all the proposed indices are individual, and therefore, it is possible to study its change both during life of a certain animal and in passing on from generation to generation.

\section{Conclusion}

It were created the indices to assess the renewal of sexual activity in ewes that are linked to fact and time of display of heat and successful insemination and show the different level of the correlation relationship with the age, the weight, traditional reproductive traits and climatic parameters.

Perspectives of the future investigations. The estimation of the developed indices on the criteria of repeatability and heritability should demonstrate the possibility of their application in tradi- tional selection. The developed indices are promising for implementation in study of effectiveness of technological methods that is aimed to reduce the influence of seasonality on sheep reproduction.

1. Aktaş A. H., Dursun Ş., Doğan Ş., Kiyma Z., Demirci U., Halıc İ. Effects of ewe live weight and age on reproductive performance, lamb growth, and survival in Central Anatolian Merino sheep. Arch. Anim. Breed, 2015, vol. 58, issue 2, pp. 451-459. DOI: 10.5194/aab58-451-2015.

2. Bartlewski P. M., Beard A. P., Cook S. J., Rawlings N. C. Ovarian follicular dynamics during anoestrus in ewes. J. Repr. Fert., 1998, vol. 113, pp. 275-285. DOI: 10.1530/jrf.0.1130275.

3. Cameron J., Malpaux B., Castonguay F. W. Accelerated lambing achieved by a photoperiod regimen consisting of alternating 4-month sequences of long and short days applied year-round. J. Anim. Sci., 2010 , vol. 88 , issue 10 , pp. $3280-3290$. DOI: $10.2527 /$ jas.2010-2911.

4. Chanvallon A., Sagot L., Pottier E., Scaramuzzi R. J., Fabre-Nys C. Interactions among seasonality of reproduction, genotype and the ram effect. Archiva Zootechnica, 2009, vol. 12, no. 3, pp. 73-81.

5. Eteqadi B., Ghavi Hossein-Zadeh N., Shadpar$\operatorname{var}$ A.A. Genetic analysis of basic and composite reproduction traits in Guilan sheep. Ann. Anim. Sci., 2017, vol. 17, issue 1, pp. 105-116. DOI: 10.1515/aoas-2016-0016.

6. Gushwa W. T., Bradford G. E., Stabenfeldtt G. H., Berger Y. M., Dally M. R. Ram influence on ovarian and sexual activity in anestrous ewes: effects of isolation of ewes from rams before joining and date of ram introduction. J. Anim. Sci., 1992, vol. 70, issue 4, pp. 1195-1200. DOI: 10.2527/1992.7041195x.

7. Karsch F. J., Bittman E. L., Foster D. L., Goodman R. L., Legan S. J., Robinson J. E. Neuroendocrine basis of seasonal reproduction. Recent Prog. Hor. Res., 1984, vol. 40, pp. 185-232. DOI: 10.1016/B978-0-12571140-1.50010-4.

8. Lobachova I. V. Ovary morphology in ewes in different months of year. The Animal Biology, 2016, vol. 18 , no. 1 , pp. $77-86$. DOI: $10.15407 /$ animbiol18.01.077. (in Ukrainian)

9. Lôbo A. M. B. O., Lôbo R. N. B., Paiva S. R., Oliveira de S. M. P., Facó O. Genetic parameters for growth, reproductive and maternal traits in a multibreed meat sheep population. Genet. Mol. Biol., 2009, vol. 32 , no. 4 , pp. 761-770. DOI: 10.1590/S141547572009005000080.

10. O'Ferrall M. G. J. A comparison of sheep breeds and crosses for ewe productivity. Ir. J. Agric. Res., 1975, vol. 14, no. 3, pp. 285-296.

11. Notter D. R., Copenhaver J. S. Performance of Finnish Landrace crossbred ewes under accelerated lambing. I. Fertility, prolificacy and ewe productivity. $J$. Anim. Sci., 1980, vol. 51, issue 5, pp. 1033-1042. DOI: $10.2527 /$ jas $1980.5151033 x$. 
12. Notter D. R. Genetic aspects of reproduction in sheep. Repr. Domestic Anim., 2008, vol. 43, issue s2, pp. 122-128. DOI: 10.1111/j.1439-0531.2008.01151.x.

13. Notter D. R. Genetic improvement of out-ofseason breeding through selection. In: D. G. Morrical (ed.) Out of Season Breeding Symposium. Iowa State Univ., Ames., 1992, pp. 55-81.

14. Notter D. R., Smith J. K., Akers R. M. Patterns of estrous cycles, estrous behavior, and circulating prolactin in spring and summer in ewes selected for autumn lambing and exposed to ambient or long-day photoperiods. Appl. Anim. Behav. Sci., 2011, vol. 129, issue 1-2, pp. 30-36. DOI: 10.1016/j.anireprosci.2011.10.008.

15. Oldham C. M., Martin G. B. Stimulation of seasonally anovular Merino ewes by rams II: Premature regression of ram-induced corpora lutea. Anim. Reprod. Sci., 1978, vol. 1, issue 4, pp. 291-295. DOI: 10.1016/0378-4320(79)90014-9.
16. Ptáček M., Ducháček J., Stádník L., Fantová M. Effects of age and nutritional status at mating on the reproductive and productive traits in Suffolk sheep kept under permanent outdoor management system. Czech J. Anim. Sci., 2017, vol. 62, pp. 211-218. DOI: $10.17221 / 63 / 2016-C J A S$.

17. Rubaines E., Menchaca A., Gil J., Olivera J. Reproductive performance of a new timed artificial insemination protocol (Synchrovine ${ }^{\mathrm{TM}}$ ) in sheep. Repr. Fert. Dev., 2004, vol. 16, p. 508.

18. Sawyer G. J., Lindsay D. R., Martin G. R. The Influence of radiant heat load on reproduction in the merino ewe. III Duration of oestrus, cyclical oestrous activity, plasma progesterone, LH levels and fertility of ewes exposed to high temperatures before mating. Aust. J. Agric. Res., 1979, vol. 30, no. 6, pp. 1151-1162. DOI: 10.1071/AR9791151. 